\title{
Efficacy of Diatomaceous Earth and Deltamethrin Alone and in Combinations on Mortality and Energy Reserves of Insecticide Resistant Strains of Stored Grain Pest, Trogoderma granarium
}

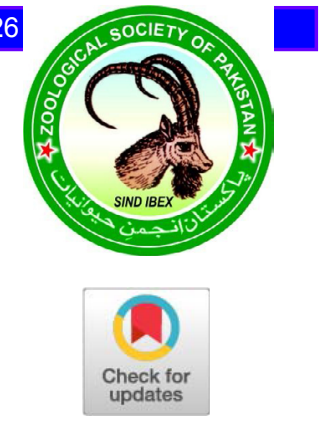

\author{
Nabila Kousar ${ }^{1}$, Tanzeela Riaz ${ }^{2}$, Anum Feroz ${ }^{1}$, Abdul Rauf Shakoori ${ }^{3}$ and \\ Farah Rauf Shakoori ${ }^{1 *}$ \\ ${ }^{1}$ Institute of Zoology, University of the Punjab, Quaid-i-Azam Campus, Lahore, Pakistan \\ ${ }^{2}$ Faculty of Life Sciences, University of the Central Punjab, Khiyaban-i-Jinnah, Johar \\ Town, Lahore, Pakistan \\ ${ }^{3}$ School of Biological Sciences, University of the Punjab, Quaid-i-Azam Campus, \\ Lahore, Pakistan
}

\begin{abstract}
A B S T R A C T
The present study was conducted to determine the $\mathrm{LC}_{50}$ of deltamethrin and diatomaceous earth (DE) alone and in different combinations i.e., 0.5:01, 01:0.5 and 1:1 against $4^{\text {th }}$ instars of insecticide resistant populations of Trogoderma granarium collected from godowns of Gujranwala (GUW), D.G. khan (DGK), Okara (OKR), Lahore (LAB-S) and Layyah. The $\mathrm{LC}_{50}$ values of deltamethrin against $4^{\text {th }}$ instar larvae of GUW, DGK, OKR, Layyah and LAB-S were 514, 353, 303, 189 and 98 ppm respectively while for the DE these values were 3606, 2684, 2407, 2192 and $2065 \mathrm{ppm}$, respectively. Based on the values of $\mathrm{LC}_{50}$ deltamethrin was found to be more effective than DE. Among the tested populations, GUW population was most resistant while LAB-S population was least resistant. Efficacy of deltamethrin and $\mathrm{DE}$ in various combinations was also tested against the same larval stage of different strains of pest populations and the mixture $0.5 \mathrm{DM}+1 \mathrm{DE}$ was found to be most effective among all mixtures on the basis of $\mathrm{LC}_{50}$ values and relative toxic unit. The toxicity of this mixture was analyzed on glucose, glycogen, trehalose, total proteins, soluble proteins, free amino acids and total lipids contents of $4^{\text {th }}$ instars larva of most resistant GUW and least resistant LAB-S populations at exposure to $\mathrm{LC}_{20}$. Among the biochemical parameters glucose, soluble proteins and FAA contents were found to be elevated significantly whereas the concentration of total proteins, glycogen, trehalose and total lipids was found to be decreased in both populations. Depletion of energy reserves is most probably the cause of mortality of the pest.
\end{abstract}

\begin{tabular}{l} 
Article Information \\
Received 07 July 2021 \\
Revised 11 August 2021 \\
Accepted 26 August 2021 \\
Available online 15 September 2021 \\
Authors' Contribution \\
\hline NK performed experimental work, \\
statistically analyzed the data and \\
prepared first draft of the manuscript. \\
TR improved the article. AF formatted \\
article. FRS and ARS designed and \\
supervised the work and also reviewed \\
the entire manuscript. \\
Key words \\
Synergism, Antagonism, Deltame- \\
thrin-DE combination, $4^{\text {th }}$ Instar \\
larvae, Grain protectants
\end{tabular}

\section{INTRODUCTION}

$\mathrm{T}$ he most widely grown crop wheat (Triticum aestivum Lam) has been considered as the basic staple food and one of the first domesticated food crops of major civilizations of Europe and of Pakistan from previous 10,000 years. All over the world as well as in Pakistan, a huge damage to stored grain products is caused by stored grain insect pests among which Trogoderma granarium (Everts) is causing a remarkable loss to wheat, cereals, grains and other stored products in Asia and Africa (Burges, 2008; Phillips and Throne, 2010; Nadur et al., 2015; Masolkar et al., 2018). Post-harvest storage losses may range from $7-10 \%$ of total production from field to purchasers and 4-5\% at marketing (Yadav et al., 2018).

\footnotetext{
Corresponding author: farah.zool@pu.edu.pk 0030-9923/2021/0006-2183 \$ 9.00/0

Copyright 2021 Zoological Society of Pakistan
}

T. granarium pass through five to six larval stages before developing into pupae and adult beetle. It completes its life cycle in 45-50 days (Kulkarni et al., 2015; Hafiz et al., 2017). Larvae of this beetle play a major role to damage the stored grain from $30-70 \%$, thus are considered best for the control strategies as they can pass through starvation for years (through diapause), developed resistance against different insecticides, feed on low moisture content and hiding in crevices and cracks (Ahmedani et al., 2009; Athanassiou et al., 2015).

Various pesticides like organophosphates, pyrethroids and carbamates have been recommended to lessen insect pest infestation (Hargreaves et al., 2000). The pyrethroids possessed different level of toxicity. Deltamethrin is most widely used in storage facilities to control the insect pest infestation. It acts by causing rapid paralysis of the nervous system by a sudden knockdown and disable insects feeding. It also causes poisoning through cuticular penetration or through oral uptake that led to permanent 
nervous breakdown (Leahey, 1985; Hayes and Laws, 1990). It is a Type 11 a-cyano synthetic pyrethroid (Casida and Durkin, 2013) and is graded as acute hazard in class 2 of WHO insecticide toxicity classification (WHO, 2009). It considered three times more toxic as compared to other synthetic insecticides (Gilbert, 2014). Synthetic pesticides posed various types of ecological problems, high mammalian toxicity and prone to emergence of insecticide resistance (Chintzoglou et al., 2008). Therefore, the researchers shifted their efforts towards biopesticide to reduce and ultimately eliminate the use of synthetic pesticides on which smallholder farmers currently rely on due to lack of effective alternatives (Vassilakos et $a l ., 2015)$. In this context DE is a bio insecticide derived from fossilized deposits of siliceous marine or fresh water unicellular algae and mainly composed of silicon dioxide (Shah and Khan, 2014). It causes disruption of the lipid layer, physical abrasion and insects die due to dryness. Various formulations of DE are effective against many pest species like Tribolium castaneum Herbst and Tribolium confusum Duval (Athanassiou and Steenberg, 2007). The available literature also pointed out that the required $\mathrm{DE}$ dosage to effectively control insect pests is about $1000 \mathrm{ppm} /$ tonne (Athanassiou and Korunic, 2007; Athanassiou et al., 2013) is very high for safety of workers as well it possessed toxic effect on density and quality of grains (Vayias et al., 2009; Korunic, 2013).

Due to the above-mentioned disadvantages of DE many researchers have recommended low dosage of DE (Korunic and Rozman, 2010; Almasi et al., 2013). The toxicity of such low doses could be enhanced by synergistic combinations of DEs with different additives as mentioned by (Athanassiou and Korunic, 2007; Korunic and Rozman, 2010; Almasi et al., 2013). The success rate of these combinations is dependent on various factors like humidity, temperature, insect species, insect sources and characteristics of the particular DE (Athanassiou et al., $2005,2008)$. So, by using these combination of selective biological insecticides, emergence of resistance can be delayed that can provide very effective extended grain protection. It is the most favorable managing approach under different life histories of insect. Moreover, in mixture, various pesticides may develop synergism at much lower concentrations (O'Connor-Marer, 2000; Athanssiou et al., 2005; Cloyd, 2011; Machekano et al., 2017). These combinations may be cost-effective due less quantity of individual insecticides used, less number of applications required for a short period and comparatively less toxicty to famers and environment (Das, 2014). Deltamethrin and DE are often used in mixture strategy. Due to combined action, the concentrations of DE and various other pesticides concentrations in the mixtures are used in smaller amount than used alone. This combination acts at different modes of action, desiccation and chemical toxicity (Vayias et al., 2009; Korunic, 2013, 2016; Machekano et al., 2017; Delgarm et al., 2020).

Due to the rising resistance problem against conventional pesticides, environmental hazards, shortcoming related to DE and to reduce the deltamethrin residue in grains as well as considering the importance of synergism, the present study was planned to find out (1) toxicity of DE and deltamethrin when applied alone (2) toxicity of various combinations of DE and deltamethrin (3) to determine the toxic effect of the most effective mixture on energy reserves of the $4^{\text {th }}$ instar larvae of $T$. granarium.

\section{MATERIALS AND METHODS}

\section{Collection and rearing of insects}

In current study four populations of T. granarium were collected from wheat storing godowns of Pakistan Agricultural Storage and Service Corporation Ltd in Okara (OKR), Gujranwala (GUW), Layyah and Dera Ghazi Khan (DGK) in Punjab, Pakistan. The wheat stored in godowns is being treated with deltamethrin for more than 38 years to manage the invasion of notorious insect pest especially the $T$. granarium. Lahore population of khapra beetle (LAB-S) reared in the insectary for more than 18 years without any exposure to fumigant or insecticides was used to grade the level of resistance in field collected deltamethrin resistant populations.

Different larval stages i.e. $1^{\text {st }}, 2^{\text {nd, }} 3^{\text {rd }}, 4^{\text {th }}, 5^{\text {th }}, 6^{\text {th }}$ and adult beetles were maintained in sterilized jam jars $(300 \mathrm{ml})$ separately in a culture room at $30_{ \pm} 1^{\circ} \mathrm{C}$ and $65 \pm 5 \%$ relative humidity (R.H) according to Riaz et al. (2014, 2018). To culture the T. granarium wheat grain, were used as a culture media. In each plastic jar containing $250 \mathrm{~g}$ sterilized wheat grain, $24 \mathrm{~h}$ old adult unmated beetles (100) with no sex discrimination were released. Each jar was covered with muslin cloth to prevent the escape of insects and from the attack of any other pest. Beetles were allowed to lay eggs and then separated from the flour. The flour containing eggs was poured back into the jars. After $32 \pm 2$ days of developmental period, hundred newly emerged adults were resealed again in another set of jars containing flour for egg laying. This process was repeated 4-5 times to attain homogenous populations (Riaz et al., 2018). From this homogenous culture, after $15 \pm 2$ days of egg hatching, $4^{\text {th }}$ instar larvae were collected for estimation of $\mathrm{LC}_{50}$ and other toxicological studies.

\section{Insecticides used}

In this study technical grades of synthetic pyrethroid, 
deltamethrin $\left(\mathrm{C}_{22} \mathrm{H}_{19} \mathrm{Br}_{2} \mathrm{NO}_{3}\right)$ [(S)-Cyano-(3-phenoxyphenyl)-methyl] (1R,3R)-3-(2,2-dibromoethenyl)-2,2-dimethyl-cyclopropane-1-carboxylate) $(1.5 \% \mathrm{EC}, \mathrm{w} / \mathrm{v})$ was purchased from Agrochemicals (Private) Limited, Wahdat Road, Lahore. Diatomaceous Earth $\left(\mathrm{SiO}_{2} 90 \%+\right.$ inert ingredient $10 \%$ ) was obtained in wettable powdered (WP) from The Planters (Pvt) Ltd (TPL Services) Islamabad. For the preparation of different concentration of insecticides, absolute acetone was used as a solvent.

\section{Preparation of stock and working solutions of deltamethrin and diatomaceous earth}

The stock solutions of $4000 \mathrm{ppm}$ of deltamethrin (1.5\% EC) and 1.5\% WP of DE were used for preparation of working solutions. The working solutions were mixed in different proportions at room temperature as shown in Table I. Final concentration of each combination was kept $4000 \mathrm{ppm}$ in both sets in $10 \mathrm{ml}$ total volume.

Table I. Composition of deltamethrin and diatomaceous earth combinations used for the estimation of $\mathrm{LC}_{50}$ values against populations of $T$. granarium.

\begin{tabular}{llll}
\hline $\begin{array}{l}\text { Mix- } \\
\text { ture }\end{array}$ & $\begin{array}{l}\text { Ratios } \\
\text { deltame- } \\
\text { thrin: DE }\end{array}$ & \multicolumn{1}{c}{$\begin{array}{c}\text { Concentration and quantity of } \\
\text { component insecticides mixed } \\
\text { (volume/volume) }\end{array}$} \\
\cline { 3 - 4 } & & $\begin{array}{l}\text { Deltamethrin } \\
\text { (4000 ppm) }\end{array}$ & $\begin{array}{l}\text { Diatomaceous } \\
\text { earth (4000 ppm) }\end{array}$ \\
\hline 1 & $0.5: 1$ & $5 \mathrm{ml}(2000 \mathrm{ppm})$ & $5 \mathrm{ml}(2000 \mathrm{ppm})$ \\
2 & $1: 0.5$ & $2.5 \mathrm{ml}(1000 \mathrm{ppm})$ & $7.5(3000 \mathrm{ppm})$ \\
3 & $1: 1$ & $7.5(3000 \mathrm{ppm})$ & $2.5 \mathrm{ml}(1000 \mathrm{ppm})$ \\
\hline
\end{tabular}

\section{Dose bioassay}

For estimation of $\mathrm{LC}_{50}$ of deltamethrin, $\mathrm{DE}$ and those combinations of deltamethrin and DE mentioned in Table I, various concentrations such as 200-4000 ppm (on a scale of $200 \mathrm{ppm}$ ) of each insecticide were prepared in absolute acetone. Each concentration of deltamethrin, DE and their combinations was administered to $4^{\text {th }}$ instar larvae of OKR, DGK, GUW, Layyah and LAB-S populations according to the residual film method (Busvine, 1971; Saleem and Shakoori, 1990; Shakoori et al., 2004). Aliquot of 1ml from each concentration of each insecticide was applied in respective labelled petri dishes (dia. $4.5 \mathrm{~cm}$ ) to form a uniform coating. The petri plates were air dried for 5 min to evaporate the solvent and formation of a thin film of insecticide was observed. Absolute acetone $(1 \mathrm{ml})$ was applied in control petri dishes and it was evaporated. Ten healthy $4^{\text {th }}$ instar larvae (with no sex discrimination) from OKR, DGK, GUW, Layyah and LAB-S strains of $T$. granarium were transferred to these respective petri dishes at $30_{ \pm} 1^{\circ} \mathrm{C}$ and $65 \pm 5 \% \mathrm{r}$.h for $48 \mathrm{~h}$. The entire procedure was replicated three times. After the subsequent pesticide exposure period, mortality was observed for every treatment as described by Lloyd (1969). By using Minitab 16 software the mortality data was subjected to Probit analysis described by Finney (1971) for estimation of $\mathrm{LC}_{50}$ and $\mathrm{LC}_{20}$ at $95 \%$ fiducial limit and values of the slope. The level of resistance in $4^{\text {th }}$ instar larvae of field collected populations of khapra beetle against each treatment were determined at $\mathrm{LC}_{50}$ level by comparing with LAB-S strain using resistance ratio (RR) by following the criteria described by Mazzarri and Georghiou (1995).

\section{Synergistic interactions}

Synergistic, antagonistic or additive interactions between the constituent insecticides for all the mixtures were calculated at $\mathrm{LC}_{50}$ value in terms of relative toxic unit (RTU) (Otitoloju, 2001).

$$
\text { Relative Toxic Unit }=\frac{\text { Theoretical LC50 of mixture }}{\text { Observed LC50 of mixture }}
$$

Theoretical $\mathrm{LC}_{50}$ of mixture $=\left(\mathrm{LC}_{50}\right.$ of insecticide $\mathrm{A}$ alone $\times$ Percentage of $\mathrm{A}$ in Mixture $)+\left(\mathrm{LC}_{50}\right.$ of insecticide $B$ alone $\times$ Percentage of $B$ in Mixture).

Mixture exhibited synergism if the calculated relative toxic unit is higher than 1 and antagonism if these values are less than 1 .

\section{Administration of $\mathrm{LC}_{20}$}

Based on RR value, GUW strain were considered most resistant and LAB-S was considered least resistant strains of khapra beetle. The $4^{\text {th }}$ instar larvae (1000) of these populations were exposed to $\mathrm{LC}_{20}$ of mixture $2(0.5$ deltamethrin: $1 \mathrm{DE}$ ) following the procedure as mentioned in the section of "Dose bioassay". The mortality is very low at $\mathrm{LC}_{20}$ value so, this treatment provided an insight about the toxic effects of mixture on energy reserves of $T$. granarium.

\section{Biochemical assay}

To evaluate the toxic effects of mixture on various energy reserves, twenty larvae of $T$. granarium from GUW and LAB-S populations were weighed and homogenized in $2 \mathrm{ml}$ of saline solution $(0.89 \%)$ in a Teflon glass homogenizer at $4^{\circ} \mathrm{C}$. The homogenate was centrifuged at $13500 \mathrm{rpm}$ for $15 \mathrm{~min}$ at $4^{\circ} \mathrm{C}$. In order to evaluate the toxic effects exerted by the mixture, untreated larvae of these populations were also proceeded in this way. The supernatants were used for the estimation of trehalose through anthrone method described by Carroll et al. (1956), soluble proteins according to Lowry et al. (1951) and glucose contents by O-toluidine method of Hartel et al. (1969). The method adopted for the estimation of 
lipids, was of Zollner and Kirsch (1962) and free amino acid contents was quantified according to Moore and Stein (1954) by using ethanolic extract of larvae. Anthrone methodology of Consolazio and Lacono (1963) was followed for glycogen contents and homogenate was prepared in $30 \%$ potassium hydroxide solution and extract for total protein contents was prepared in $\mathrm{NaOH}$ and estimation was done according to Lowry et al. (1951). For the effects of sub-lethal doses of mixture, unpaired " $t$ " test at $95 \%$ confidence limit was used.

\section{RESULTS AND DISCUSSION}

Table II indicates the comparison of $\mathrm{LC}_{50}$ of deltamethrin, DE and in mixtures against $4^{\text {th }}$ instar larvae of LAB-S and four deltamethrin tolerant strains of $T$. granarium. No mortality was observed in control petri plates for the all the sets of replicates.

\section{Toxicity of individual insecticides}

The $\mathrm{LC}_{50}$ of deltamethrin for $4^{\text {th }}$ instar larvae of Layyah, OKR, GUW, DGK and LAB-S populations was $353,189,514,303$ and 98 ppm, respectively while $\mathrm{LC}_{50}$ values of DE was 3606, 2684, 2407, 2192 and 2065 ppm, respectively. Deltamethrin was found to be the most effective while DE was the least effective insecticide when administered alone. From all the tested populations, larvae of GUW population were the most resistant (RR 5.24) while the larvae of OKR population were the least resistant to deltamethrin (RR 2.02) in comparison to $\mathrm{LC}_{50}$ value of LAB-S population. All populations have very

Table II. $\mathrm{LC}_{50}$ of deltamethrin and DE and comparison of their efficacies in combinations against $4^{\text {th }}$ instar larvae of one susceptible and three deltamethrin tolerant strains of T. granarium.

\begin{tabular}{|c|c|c|c|c|c|c|c|c|c|}
\hline $\begin{array}{l}\text { Insecticides/ } \\
\text { mixture used }\end{array}$ & Ratio & $\begin{array}{l}\text { Locality of } \\
\text { population }\end{array}$ & $\begin{array}{l}\mathbf{L C}_{50} \\
(\mathbf{p p m}) \pm \mathbf{S E M}^{*}\end{array}$ & $95 \%$ Fiducial limits & Slope \pm SE & $\chi^{2}$ & $\mathbf{P}^{* * *}$ & $\mathbf{R} \mathbf{R}^{* * *}$ & $\mathbf{R T U}^{* * * * *}$ \\
\hline \multirow[t]{5}{*}{ Deltamethrin } & \multirow[t]{5}{*}{$1: 0$} & GUW & $513.80 \pm 0.12$ & $473.80-553.80$ & $9.23 \pm 2.15$ & 0.83 & 0.11 & 5.24 & ------ \\
\hline & & Layyah & $353.17 \pm 0.18$ & $303.17-403.18$ & $0.01 \pm 0.02$ & 2.59 & 0.98 & 3.60 & ------ \\
\hline & & DGK & $303.07 \pm 0.14$ & $283.08-323.07$ & $7.93 \pm 1.33$ & 4.92 & 0.89 & 3.10 & ------ \\
\hline & & OKR & $188.86 \pm 0.05$ & $163.84-213.90$ & $7.50 \pm 1.35$ & 4.65 & 0.91 & 2.02 & ----- \\
\hline & & LAB-S & $97.92 \pm 0.09$ & $67.92-127.89$ & $4.47 \pm 0.77$ & 3.76 & 1.05 & ----- & ----- \\
\hline \multirow{5}{*}{$\begin{array}{l}\text { Diatomaceous } \\
\text { Earth }\end{array}$} & \multirow[t]{5}{*}{$1: 0$} & GUW & $3605.87 \pm 0.17$ & $3205.40-4005.27$ & $13.04 \pm 2.74$ & 0.89 & 0.26 & 1.74 & ----- \\
\hline & & Layyah & $2684.31 \pm 0.021$ & $2384.11-2984.51$ & $22.81 \pm 4.17$ & 3.12 & 0.85 & 1.30 & ----- \\
\hline & & DGK & $2406.56 \pm 0.31$ & $2200.56-2612.30$ & $15.11 \pm 2.41$ & 2.12 & 0.89 & 1.16 & ----- \\
\hline & & OKR & $2191.95 \pm 0.48$ & $1840.40-2543.40$ & $19.04 \pm 3.60$ & 7.40 & 0.59 & 1.06 & ----- \\
\hline & & LAB-S & $2064.55 \pm 0.09$ & $1624.33-2484.77$ & $24.03 \pm 5.76$ & 1.59 & 0.99 & ----- & ------ \\
\hline \multirow{5}{*}{$\begin{array}{l}\text { Mixture } 1 \\
\text { deltamethrin: }\end{array}$} & \multirow[t]{5}{*}{$0.5: 1$} & GUW & $663.58 \pm 0.31$ & $563.28-763.81$ & $3.62 \pm 2.65$ & 0.15 & 0.92 & 3.42 & 5.82 \\
\hline & & Layyah & $562.71 \pm 0.21$ & $356.41-769.01$ & $1.69 \pm 0.79$ & 0.02 & 0.99 & 2.90 & 5.08 \\
\hline & & DGK & $402.51 \pm 0.32$ & $199.21-605.81$ & $1.73 \pm 0.73$ & 0.26 & 0.88 & 2.08 & 6.35 \\
\hline & & OKR & $213.015 \pm 0.17$ & $163.60-263.51$ & $2.21 \pm 0.78$ & 2.46 & 0.29 & 1.10 & 10.73 \\
\hline & & LAB-S & $194.36 \pm 0.23$ & $144.15-244.55$ & $2.69 \pm 1.27$ & 1.08 & 0.58 & ------ & 10.87 \\
\hline \multirow{5}{*}{$\begin{array}{l}\text { DE mixture } 2 \\
\text { deltamethrin: DE }\end{array}$} & \multirow{5}{*}{$1: 0.5$} & GUW & $793.44 \pm 0.42$ & $690.28-896.60$ & $3.62 \pm 2.65$ & 0.15 & 0.93 & 2.62 & 2.91 \\
\hline & & Layyah & $663.59 \pm 0.18$ & $423.18-903.98$ & $2.56 \pm 1.19$ & 0.36 & 0.83 & 2.19 & 2.55 \\
\hline & & DGK & $501.89 \pm 0.24$ & $399.19-604.69$ & $1.99 \pm 0.80$ & 0.13 & 0.93 & 1.66 & 3.00 \\
\hline & & OKR & $322.38 \pm 0.61$ & $272.17-377.57$ & $2.85 \pm 0.83$ & 2.82 & 0.42 & 1.06 & 3.98 \\
\hline & & LAB-S & $303.40 \pm 0.04$ & $197.18-409.22$ & $2.47 \pm 0.83$ & 1.22 & 0.54 & ----- & 3.72 \\
\hline \multirow{5}{*}{$\begin{array}{l}\text { Mixture } 3 \\
\text { deltamethrin: DE }\end{array}$} & \multirow{5}{*}{$1: 1$} & GUW & $1723.03 \pm 0.24$ & $1520.20-1926.07$ & $4.13 \pm 1.08$ & 0.77 & 0.99 & 2.80 & 1.34 \\
\hline & & Layyah & $1471.99 \pm 0.27$ & $1520.20-1926.07$ & $5.58 \pm 1.20$ & 0.40 & 0.99 & 2.37 & 1.15 \\
\hline & & DGK & $1070.56 \pm 0.07$ & $768.20-1372.86$ & $3.74 \pm 0.71$ & 9.43 & 0.31 & 1.73 & 1.41 \\
\hline & & OKR & $748.91 \pm 0.16$ & $698.41-799.41$ & $2.69 \pm 0.52$ & 8.12 & 0.42 & 1.21 & 1.71 \\
\hline & & LAB-S & $619.68 \pm 0.27$ & $469.50-769.86$ & $3.67 \pm 0.64$ & 8.57 & 0.37 & ----- & 1.82 \\
\hline
\end{tabular}

${ }^{*}$ Mean \pm standard error of mean; ${ }^{* *}$ Degree of freedom for all experiments $=19 ;{ }^{* * *}$ Resistance ratio (RR): Resistance level High $($ RR $>10)$ Moderate $(5<$ $\mathrm{RR}<10)$ Low $(\mathrm{RR}<5) ;{ }^{* * * *}$ Relative toxic unit: (RTU) 1 (additive action), $<1$ (antagonism), or $>1$ (synergism). 
low RR value in case of DE administration (Table II). Our findings revealed that the field collected populations are gradually developing resistance against deltamethrin due to its inappropriate application in stored product facility (Rossi et al., 2010; Wakil et al., 2018). Feroz et al. (2020) reported deltamethrin resistance in $4^{\text {th }}$ and $6^{\text {th }}$ instar larvae of T. granarium. Delgram et al. (2020) documented tolerance against deltamethrin in $T$. confusum and $R$. dominica. Likewise, Lorini and Galley (2000) reported deltamethrin resistance in different strains of $R$. dominica. Moreover, the results indicated that low mortality was observed when DE was used alone against all the tested populations. These findings are in accordance with Machekano et al. (2017) who documented low efficacy of DE alone against T. castaneum, Prostephanus truncates and S. zeamais. The low efficacy of DE when administered alone may be due to various factors like RH (Stathers et al., 2004), source of insect pest (Vayias et al., 2009), temperature (Athanassiou et al., 2005) and properties of DE (Korunic, 2013; Nwaubani et al., 2014).

\section{Synergistic effect of insecticides}

Based on values of RTU, the mixture 1 (0.5DM:1DE) of deltamethrin and DE showed strongest synergistic relationship in $4^{\text {th }}$ instar larvae of all populations. This mixture showed highest synergism (10.87 and 10.73 RTU values) for $\mathrm{LAB}-\mathrm{S}$ and $\mathrm{OKR}$ population respectively. For Mixture $2(1 \mathrm{DM}+0.5 \mathrm{DE})$ a strong synergistic association (RTU 2.91, 2.55, 3.003 .98 and 3.72) was observed in $4^{\text {th }}$ instar larvae of GUW, Layyah, DGK, OKR and LAB-S populations respectively. In the mixture 3 (1DM:1DE) a weaker synergistic relationship (RTU 1.34, 1.15, 1.41, 1.71 and 1.82) was observed in GUW, Layyah, DGK, OKR and LAB-S populations respectively. The mixture 1 containing higher concentration of DE and lower concentration of DM was found to be more effective than the other two mixtures against all populations. Synergistic or antagonistic relationship is based on the type of insecticide, their mode of action, concentrations used in mixture and the class of insect pest as proposed by Khan et al. (2013). Our findings are in accordance to Ceruti and Lazzari (2005) who reported the control of $S$. zeamais by combination of deltamethrin and DE. Similarly, Korunic and Rozman (2010) also documented that combination of deltamethrin and DE is more effective as compared to individual insecticide. They used various combinations of deltamethrin and DE to control S. zeamais, R.dominica and T. casteneum. Our results are also in accordance to Machekano et al. (2017) who documented synergistic effect of deltamethrin and DE against $S$. zeamais. T. castaneum and $P$. truncates. Vayias et al. (2009) findings are in agreement to the current results. They reported higher efficacy of mixture of deltamethrin and DE against T. confusum as compared to treatment with individual insecticide. It was proposed that combination of deltamethrin and DE with different mode of action like toxicity induced by deltamethrin and physical disruption of epicuticle by DE caused a negative effect on insect pest (Cook et al., 2008). The desiccated insect pests had reduced activities like mating, feeding and oviposition due to physiological stress of DE (Arthur, 2000; Korunic, 2013, 2016) and they became prone to deltamethrin toxicity (Korunic and Rozman, 2010; Machekano et al., 2017). The synergistic interaction among tested mixtures in current study indicated that there is a complementary efficacy between deltamethrin and DE combinations which can be used in field as an IPM strategy in stored grain facilities to suppress the development of resistance in postharvest system. Machekano et al. (2017) documented deltamethrin and DE combination is effective where T. cataneum is the target species and DE-spinosad combination is effective where $P$. truncates is the target insect pest while both combinations are found effective against $S$. zeamais. The deltamethrin and DE combination is also effective against $T$. granarium as revealed in current studies. So, there is a dire need to test such combinations against other insect pests of stored grain commodities to achieve a proper control against stored grain insect pests. The choice of combinations by farmers and grain handlers also depends on the cost and availability of the combinations (Machekano et al., 2017).

\section{Effect on energy reserves}

Table III shows the effect of mixture $1(0.5 \mathrm{DM}+1 \mathrm{DE})$ at $\mathrm{LC}_{20}$ concentration on energy reserves of $4^{\text {th }}$ instar larvae of GUW and LAB-S populations of T. granarium. Change in percent concentration of these metabolites in exposed group with reference to unexposed group of the similar population was shown in (Fig. 1). Among the biochemical parameters glucose, soluble proteins and FAA contents were found to be up regulated significantly in response to insecticidal treatment. Whereas the concentrations of total proteins, glycogen, trehalose and total lipids in treated groups of $4^{\text {th }}$ instar larvae were down regulated with reference to the untreated groups.

The present investigation was also designed to find out the biochemical basis of effects of mixture 1 against resistant and susceptible populations of $T$. granarium. Invasion of khapra beetle is treated with various types of pesticides during storage process in godowns that effect different biomolecules having crucial role in behavioral, physiological and biochemical responses of an organism (Yazdani et al., 2013). The increased levels of glucose and decreased level of glycogen and trehalose in these populations after $48 \mathrm{~h}$ contact to the most effective 
combination showed that larvae required more energy to deal with the stress conditions. This elevated level of glucose may propose that glycolysis process was started to deal with in the strain induced by combination of deltamethrin and DE in which glycogen and trehalose are converted into glucose that is noticeable from increased level of glucose and decrease in glycogen and trehalose level. Hafiz et al. (2017) also reported similar findings when treated T. granarium with deltamethrin. Shakoori et al. (2018a and b) also revealed similar exposure results with the mixture of esfenvalerate, phopshine and $\lambda$-Cyhalothrin respectively on $T$. granarium.

Table III. Effect of mixture $1 \quad(0.5 D M+1 D E)$ administrated at $\mathrm{LC}_{20}$ for $48 \mathrm{~h}$ on energy related molecules and other metabolites of $4^{\text {th }}$ instar larvae of T. granarium.

\begin{tabular}{llll}
\hline Metabolites & $\begin{array}{l}\text { Popula- } \\
\text { tions }\end{array}$ & $\begin{array}{l}\text { Untreated group } \\
(\boldsymbol{\mu g} / \mathbf{m g}) * *\end{array}$ & $\begin{array}{l}\text { Treated group } \\
(\boldsymbol{\mu g} / \mathbf{m g})\end{array}$ \\
\hline Glucose & GUW & $41.43 \pm .20^{*}$ & $71.39 \pm 0.27$ \\
& LAB-S & $26.32 \pm 41$ & $42.51 \pm 0.20$ \\
Glycogen & GUW & $487.01 \pm 0.40$ & $135.39 \pm 0.08$ \\
& LAB-S & $285.00 \pm 0.35$ & $59.88 \pm 0.30$ \\
Trehalose & GUW & $6787.87 \pm 0.14$ & $2626.26 \pm 0.10$ \\
& LAB-S & $5268.08 \pm 0.27$ & $1808.08 \pm 0.51$ \\
Total pro- & GUW & $104.75 \pm 0.46$ & $45.01 \pm 0.47$ \\
teins & LAB-S & $98.34 \pm 0.23$ & $30.82 \pm 0.43$ \\
Soluble & GUW & $52.69 \pm 0.20$ & $80.16 \pm 0.30$ \\
proteins & LAB-S & $43.34 \pm 0.41$ & $58.55 \pm 0.50$ \\
Free amino & GUW & $112.21 \pm 0.35$ & $149.32 \pm 0.52$ \\
acids & LAB-S & $78.33 \pm 0.44$ & $123.23 \pm 0.46$ \\
Total lipids & GUW & $15485.32 \pm 0.33$ & $6481.41 \pm 0.24$ \\
& LAB-S & $25971.01 \pm 0.20$ & $9434.24 \pm 0.37$ \\
\hline ", Mean \pm standard error of mean; ${ }^{* *}, \mathrm{n}=3$ (no. of replicates in each \\
experiments). & \multicolumn{3}{l}{}
\end{tabular}

Significantly increased level of soluble proteins and free amino acids was also observed after 48 hours exposure of the most effective mixture of deltamethrin and $\mathrm{DE}$ that is related to increase in production of protein due to enzyme stimulation to control the toxic results of insecticide while decrease in total protein level was considered to be related to decrease in the transaminases activity as shown by Shakoori et al. (1994) and Hafiz et al. (2017) after exposure to the Sumicidan Super, a synthetic pyrethroid to larvae of $T$. castaneum and deltamethrin to larvae of T. granarium. Similarly, Bizhannia et al. (2005) also supported these changes in protein that are degraded to amino acids to continue the metabolic process through citric acid cycle. Ali et al. (2011) and Hussain et al. (2012) also revealed the elevation in FAA contents in $T$. castaneum with exposed to abamectin.

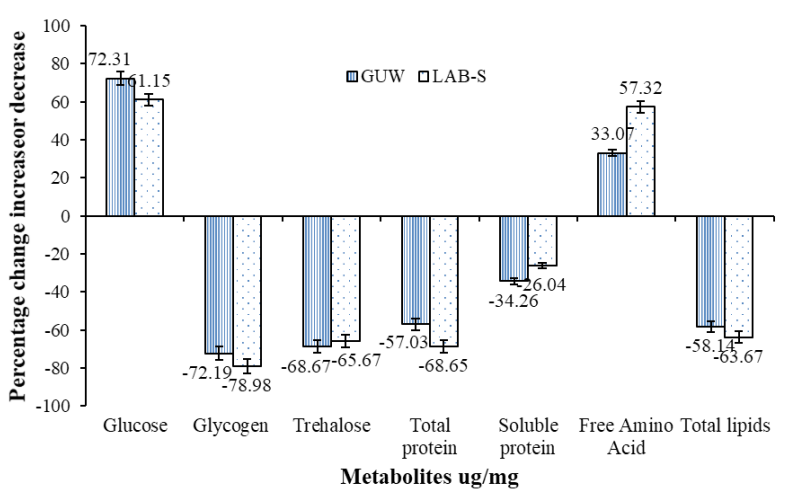

Fig. 1. Effect of mixture $1(0.5 \mathrm{DM}+1 \mathrm{DE})$ administrated at $\mathrm{LC}_{20}$ for $48 \mathrm{~h}$ on the percent increase (+) or decrease (-) in metabolites of $4^{\text {th }}$ instar larvae of $T$. granarium of GUW and LAB-S population.

Lipid contents were found to be decreased in current study due to conversion of lipid to protein to provide the energy source under the condition of stress produced by the pesticide mixture. Similar effect on lipid and glycogen contents induced by various insecticides were observed by Omar et al. (2005), Ali et al. (2007), Shoba et al. (2011), Ali et al. (2011), Shaurub and Aziz (2015), Shakoori et al. (2016) and Hafiz et al. (2017). These findings are in partial agreement to Riaz et al. (2019) who reported similar effects in biomolecules after exposure to abamectin:emamectin and abametin:spinosad combinations in $4^{\text {th }}$ and $6^{\text {th }}$ instar larvae of T. granarium.

\section{CONCLUSION}

The emergence of deltamethrin resistance is increasing in godowns. The use of DE alone is not effective in ware houses of Pakistan but the combinations of deltamethrin and DE was found to be effective in control measures of T. granarium. There is also an opportunity to discover the toxic effect of these combinations with addition of some other insecticides (which are already reported in literature) as a single combination at much less concentration to possibly counter the tolerance induced against either of the components when applied alone. The use of these potential effective combination treatments could help to delay the development of insect pest resistance against individual insecticides while promoting safer food in Pakistan. Moreover, the abnormalities induced in the key biochemical components of khapra beetle by $\mathrm{LC}_{20}$ of binary combination showed that it is highly susceptible to the mixtures of insecticides. So, the use of this synergistic 
method can effectively control this insect pest in godowns.

\section{ACKNOWLEDGMENTS}

Research work in this paper did not get any specific financial support from funding agencies in the public, commercial, or not-for-profit sectors. The senior author, Prof. Dr. Farah Rauf Shakoori is highly grateful to the University of the Punjab, Lahore, Pakistan for providing research facilities.

\section{Statement of conflict of interest}

The authors have declared no conflicts of interest.

\section{REFERENCES}

Ahmed, M.A., Naqvi, S.N.H., Azmi, M.A. and Aslam, M., 2006. Effect of pesticide residues on health and different enzyme levels in the blood of farm workers from Gadap (rural area) KarachiPakistan. Chemosphere, 64: 1739-1744. https://doi. org/10.1016/j.chemosphere.2006.01.016

Ahmedani, M., Haque, M., Afzal, S., Aslam, M. and Naz, S., 2009. Varietal changes in nutritional composition of wheat kernel (Triticum aestivum L.) caused by Khapra beetle infestation. Pakistan J. Bot., 41: 1511-1519.

Ali, N.S., Ali, S.S. and Shakoori, A.R., 2011. Effect of sublethal doses of Talstar on biochemical components of malathion-resistant and-susceptible adults of Rhyzopertha dominica. Pakistan J. Zool., 43: 879-887.

Ali, N.S., Munir, M., Ali, S.S. and Shakoori, A.R., 2007. Efficacy of mixtures of an organophosphate, malathion and a synthetic pyrethroid, deltamethrin against lesser grain borer, Rhyzopertha dominica. Pakistan J. Zool., 39: 179-184.

Almasi, R., Posloncec, D. and Korunic, Z., 2013. Possible new insecticides in the protection of stored wheat. Bulg. J. agric. Sci., 19: 1078-1086.

Arthur, F.H., 1994. Efficacy of unsynergized deltamethrin and deltamethrin + chlorpyrifosmethyl combinations as protectants for stored wheat and stored corn maize. J. Stored Prod. Res., 30: 87-94. https://doi.org/10.1016/0022474X(94)90277-1

Arthur, F.H., 2000. Impact of food sources on red and confused flour beetles (Coleoptera: Tenebrionidae) exposed to diatomaceous earths in stored product and quarantine entomology. J. econ. Ent., 93: 1347-1356. https://doi.org/10.1603/0022-049393.4.1347
Arthur, F.H., 2004. Evaluation of a new insecticide formulation (F2) as a protectant of stored wheat, maize and rice. J. Stored Prod. Res., 40: 317-330. https://doi.org/10.1016/S0022-474X(03)00023-7

Athanassiou, C.G., Kavallieratos, N.G., Tsaganou, F.C., Vayias, B.J., Dimizas, C.B. and Buchelos, C.T.H., 2003. Effect of grain type on the insecticidal efficacy of SilicoSec against Sitophilus oryzae (L.) (Coleoptera: Curculionidae). Crop Prot., 22: 1141-1147. https://doi.org/10.1016/S02612194(03)00155-8

Athanassiou, C.G., Kavalliearatos, N.G., Economou, L.R., Dinizas, C.B., Vayias B.J., Tomanovic, S. and Milutinovic, M., 2005. Persistence and efficacy of three diatomaceous earth formulations against Sitophilus oryzae (Coleoptera: Curculionidae) on wheat and barley. J. econ. Ent., 98: 1404-1412. https://doi.org/10.1603/0022-0493-98.4.1404

Athanassiou, C.G., 2006. Toxicity of beta cyfluthrin applied alone or in combination with diatomaceous earth against adults of Sitophilus oryzae (L.) (Coleoptera: Curculionidae) and Tribolium confusum (Herbst.). (Coleoptera: Tenebrionidae) on stored wheat. Crop Prot., 25: 788-794. https:// doi.org/10.1016/j.cropro.2005.10.015

Athanassiou, C.G. and Korunic Z., 2007. Evaluation of two new diatomaceous earth formulations enhanced with abamectin and bitterbarkomycin against four stored grain beetle species. J. Stored Prod. Res., 43: 468-473. https://doi.org/10.1016/j. jspr.2006.12.008

Athanassiou, C.G. and Steenberg, T., 2007. Insecticidal effect of Beauveria bassiana (Balsamo) Vuillemin (Deuteromycotina: Hypocreales) in combination with three diatomaceous earth formulations against Sitophilus granaries (L.) (Coleoptera: Curculionidae). Biol. Contr., 40: 411-416. https:// doi.org/10.1016/j.biocontrol.2006.12.001

Athanassiou, C.G., Kavallieratos, N.G., Boukouvala, M.C., Mavroforos, M.E. and Kontodimas, D.C., 2015. Efficacy of alpha-cypermethrin and thiamathoxam against Trogoderma granarium Everts (Coleoptera: Dermestidae) and Tenebrio molitor L. (Coleoptera: Tene-brionidae) on concrete. J. Stored Prod. Res., 62: 101-107. https:// doi.org/10.1016/j.jspr.2015.04.003

Bizhannia, A.R., Sorati, R. and Etebari, K., 2005. The effects of a juvenile hormone analog, admiral, application on protein metabolism of silkworm, Bombyx mori (lep: bombycidae). J. Entomol. Soc. Iran., 25: 43-55.

Burges, H.D., 2008. Development of the khapra beetle, 
Trogoderma granarium, in the lower part of its temperature range. J. Stored Prod. Res., 44: 32-35.

Busvine, J.R., 1971. A critical review of the techniques for testing insecticide. Commonwealth Agricultural Bureau, London, UK. pp. 345.

Carroll, N.V., Longley, R.W. and Roe, J.H., 1956. The determination of glycogen in liver and muscle by use of anthrone reagent. J. biol. Chem., 220: 586-593. https://doi.org/10.1016/S0021-9258(18)65284-6

Casida, J.E. and Durkin, K.A., 2013. Neuroactive insecticides: targets, selectivity, resistance and secondary effects. Annu. Rev. Ent., 58: 99-117. https://doi.org/10.1146/annurevento-120811-153645

Ceruti, F.C. and Lazzari, S.M.N., 2005. Combination of diatomaceous earth and powder deltamethrin for insect control in stored corn. Rev. Bras. Ent., 49: 580-558. https://doi.org/10.1590/S008556262005000400020

Chahal, B.S. and Ramazan, M., 1991. Multiplication of khapra beetle on wheat fumigated with phopshine, Indian J. Zool., 18: 86-87.

Chanbang, Y., Arthur, F.H., Wilde, G.E. and Throne, J.E., 2007. Efficacy of diatomaceous earth and methoprene, alone and in combination, against Rhyzopertha dominica (F.) (Coleoptera: Bostrichidae) in rough rice. J. Stored Prod. Res., 43: 396-401. https://doi.org/10.1016/j. jspr.2006.12.003

Chintzoglou, G., Athanassiou, C.G. and Arthur, F.H., 2008. Insecticidal effect of spinosad dust in combination with diatomaceous earth against two stored grain beetle species. J. Stored Prod. Res., 44: 347-353. https://doi.org/10.1016/j.jspr.2008.03.005

Cloyd, R.A., 2011. Pesticide mixtures. In: Pesticides formulations, effects, fate (ed. M. Stoytcheva). Intech Open.

Consolazio, C.F. and Iacono, J.M., 1963. Carbohydrates. In: Newer methods for nutritional biochemistry with applications and interpretations (ed. A.A. Albanese). Academic Press, New York, USA. pp. 317-367. https://doi.org/10.1016/B978-0-12048001-2.50012-0

Cook, D.A., Wakefield, M.E. and Bryning, G.P., 2008. The physical action of three diatomaceous earths against a cuticle of the flour mite, Acarus siro (L.) (Acari: Acarididae). Pest Manag. Sci., 64: 141-146. https://doi.org/10.1002/ps.1484

Das, S.K., 2014. Scope and relevance of using pesticide mixtures in crop protection: a critical review. Int. J. environ. Sci. toxicol. Res., 2: 119e123.

Delgarm, N., Ziaee, M. and McLaughlin, A., 2020.
Enhanced-efficacy Iranian diatomaceous earth for controlling two stored-product insect pests. $J$. econ. Ent., 113: 506-510. https://doi.org/10.1093/ jee/toz261

FAO, 1986. Pesticide residues in food, 1985. Evaluations Part 1. Residues. FAO Plant Prod. Prot. Paper. (Vol. 72/1), pp. 372.

Feroz, A., Shakoori, F.R., Riaz, T. and Shakoori, A.R., 2020. Development of resistance in stored grain pest, Trogoderma granarium (Everts) against deltamethrin and its effective control by synergistic toxicity of bifenthrin and chlorpyrifos. J. Stored Prod. Res., 88: 101673. https://doi.org/10.1016/j. jspr.2020.101673

Fields, P. and Korunic, Z., 2000. The effect of grain moisture content and temperature on the efficacy of diatomaceous earths from different geographical locations against stored-product beetles. J. Stored Prod. Res., 36: 1-13. https://doi.org/10.1016/ S0022-474X(99)00021-1

Finkelman, S., Navarro, S., Rindner, M. and Dias, R., 2006. Effect of low pressure on the survival of Trogoderma granarium Everts, Lasioderma serricorne (F.) and Oryzaephilus surinamensis (L.) at $30^{\circ}$ C. J. Stored Prod. Res., 42: 23-30. https://doi. org/10.1016/j.jspr.2004.09.001

Finney, D.J., 1971. Probit analysis. $3^{\text {rd }}$ edn. Cambridge University Press, London, UK. pp. 333.

Gilbert, S.G., 2014. Deltamethrin toxipedia: Connecting science and people. Available at: www.toxipedia. org/display/toxipedia/Deltamethrin (Accessed 6 June 2021).

Hafiz, A., Riaz, T. and Shakoori, F.R., 2017. Metabolic profile of a stored grain pest Trogoderma granarium exposed to deltamethrin. Pakistan J. Zool., 49: 183-188. https://doi.org/10.17582/ journal.pjz/2017.49.1.183.188

Hargreaves, K., Koekamoer, L.L. and Bruke, B.P., 2000. Anopheles funestos resistant to pyrethroid and insecticides in South Africa. J. med. vet. Ent., 14: 18-189. https://doi.org/10.1046/j.13652915.2000.00234.x

Hartel, A., Helger, R. and Lang, H., 1969. A method for determination of glucose. Z. klin. Chem. klin. Biochem., 7: 183-184. https://doi.org/10.1515/ cclm.1969.7.1.14

Hasan, M., Ahmed, F., Ashraf, K. and Ahmad, M., 1996. Survey of resistance against insecticides indifferent strains of Tribolium castaneum (Herbst.) collected from Bahawalpur Division. Pakistan Entomol., 18: 41-42.

Hayes, W.J. and Laws, E.R., 1990. Handbook of 
pesticide toxicology, General principles. Vol. 1. Academic Press, Inc., NY.

Hussain, R., Ashfaq, M. and Saleem, M.A., 2012. Effect of abamectin on body protein content and activity of selected enzymes in adults of insecticide-resistant and susceptible strains of Tribolium castaneum (Herbst) (Coleoptera: Tenebrionidae). Pakistan J. Zool., 44: 1159-1163.

Jansson, R.K. and Dybas, R.A., 1998. Avermectins: biochemical mode of action, biological activity and agricultural importance. In: Insecticides with novel modes of action (eds. I. Isaac and D. Danny). https://doi.org/10.1007/978-3-662-03565-8_9

Jood, S., Kapoor, A.C. and Singh, R., 1996. Chemical composition of cereal grains as affected by storage and insect infestation. Trop. Agric., 73: 161-164.

Khan, H.A.A., Akram, W., Shad, S.A. and Lee, J.J., 2013. Insecticide mixtures could enhance the toxicity of insecticides in a resistant dairy population of Musca domestica L. PLoS One, 8: 1-8. https://doi.org/10.1371/annotation/14f1545ccbe3-4783-b7c6-f6f9e4c4a1f4

Khattak, S.U., Sahar, U., Karim, S., Ahmad U.K. and Jabbar, A., 2000. Appraisal of rain fed wheat Lines against khapra beetle Trogoderma granarium Everts. Pakistan J. Zool., 32: 131-134.

Korunic, Z. and Rozman, V., 2010. A synergistic mixture of diatomaceous earth and deltamethrin to control stored grain insects. Julius-Kühn-Archiv., 425: 894-898.

Korunic, Z. and Rozman, V., 2010. Synergistic mixture of diatomaceous earth and deltamethrin to control stored grain insects. In: Proceedings of the $10^{\text {th }}$ international conference on stored product protection, (eds. M.O. Carvalho, P.G. Fields, C.S. Adler, F.H. Arthur, C.G., Athanassiou, J.F. Campbell, F. Fleurat-Lessard, P.W. Flinn, R.J. Hodges, A.A. Isikber, S. Navarro, R.T. Noyes, J. Riudavets, K.K. Sinha, G.R. Thorpe, B.H. Timlick, P. Trematerra, N.D.G. White), pp. 894-899, 27 June 02 July 2010. Estoril. Portugal.

Korunic, Z., 2007. Joint action of ready to use insecticide mixture of plant extract bitterbarkomycin and diatomaceous earth to control stored grain insects. In: Proceedings Seminar DDD ZUPP 2007 Disinfection, disinfestation and deratization and protection of stored agricultural products, (ed. Z. Korunic) 28-30 March 2007, Dubrovnik, Croatia, Published by "Korunic" d.o.o, Zagreb, Croatia, pp. 375-387.

Korunic, Z., 2013. Diatomaceous earths-natural insecticides. Pestic. Phytomed., 28: 77-95. https://
doi.org/10.2298/PIF1302077K

Korunic, Z., 2016. Overview of undesirable effects of using diatomaceous earths for direct mixing with grains. Pestic. Phytomed., 32: 9-18. https://doi. org/10.2298/PIF1602009K

Kulkarni, V.N., Gupta, S., Kataria, R. and Sathyanarayana, 2015. Morphometric analysis and reproductive system studies of Trogoderma granarium Everts (Coleoptera: Dermestidae). Int. J. Sci. Res. Publ., 5: 1-8.

Le Patourel, G.N.J. and Singh, J., 1984. Toxicity of amorphous silicas and silica pyrethroids mixtures to Tribolium castaneum (Herbst) (Coleoptera: Tenebrionidae). J. Stored Prod. Res., 20: 183-190. https://doi.org/10.1016/0022-474X(84)90002-X

Leahey, J.P., 1985. The pyrethroid insecticides. Taylor and Francis. London and Philadelphia.

Lessard, F., Vidal, M.M. and Budzinski, H., 1998. Modeling biological efficacy decrease and rate of degradation of chlorpyrifos methyl on wheat stored under controlled conditions. J. Stored Prod. Res., 34: 341-354. https://doi.org/10.1016/S0022474X(98)00013-7

Lloyd, C.J., 1969. Study on the cross tolerance to DDT related compounds of a pyrethrin-resistant strain of Sitophilus granaries L. (Coleoptera: Curculionidae). J. Stored Prod. Res., 5: 337-356. https://doi.org/10.1016/0022-474X(69)90007-1

Lorini, I. and Galley, D.J., 2000. Effect of the synergists piperonyl butoxide and DEF in deltamethrin resistance on strains of Rhyzopertha dominica (F.) (Coleoptera: Bostrychidae). An. Soc. Entomol. Brasil., 29: 749-755. https://doi.org/10.1590/ S0301-80592000000400015

Lowry, O.H., Rosebrough, N.J., Farr, A.L. and Randall, R.J., 1951. Protein measurement with the Folin phenol reagent. J. biol. Chem., 193: 265-275. https://doi.org/10.1016/S0021-9258(19)52451-6

Machekano, H., Mvumi, B.M., Chinwada, P., Richardson-Kageler, S.J. and Rwafa, R., 2017. Efficacy of diatomaceous earths and their lowdose combinations with spinosad or deltamethrin against three beetle pests of stored-maize. J. Stored Prod. Res., 72: 128-137. https://doi.org/10.1016/j. jspr.2017.04.009

Masolkar, D.S., Gawande, R.W., Chandrawanshi, P.G. and Shinde, S.S., 2018. Management of khapra beetle on stored wheat with organic products. $J$. Pharmacogn. Phytochem., 7: 3465-3471.

Mazzarri, M.B. and Georghiou, G.P., 1995. Characterization of resistance to organophosphate, carbamate, and pyrethroid insecticides in field 
populations of Aedes aegypti from Venezuela. $J$. Am. Mosq. Contr. Assoc., 11: 315-322.

Morre, S. and Stein, W.H., 1954. A modified ninhydrin reagent for the photometric determination of amino acids and related compounds. J. biol. Chem., 211: 907- 913. https://doi.org/10.1016/S00219258(18)71178-2

Naveenaa, N.L., Suryanarayana, S. and Siddappa, S., 2015. Diversity and distribution of stored grain insects among the Soliga Tribal settlements of Biligirirangana Hills, Karnataka, India. J. Stored Prod. Res., 62: 84-92 https://doi.org/10.1016/j. jspr.2015.04.002

Nwaubani, S.I., Opit, G.P., Otitodun, O.G. and Adesia, M.A., 2014. Efficacy of two Nigerian diatomaceous earths against Sitophilus oryzae (Coleoptera: Curculionidae) and Rhyzopertha dominica (Coleoptera: Bostrichidae) on wheat. J. Stored Prod. Res., 59: 9-16. https://doi.org/10.1016/j. jspr.2014.04.001

O'Connor-Marer, P.J., 2000. Pesticides. In: The safe and effective use of pesticides (ed. P.J.O. ConnorMarer). University of California Agricultural and Natural Resources. Communication Services, Oakland, CA. pp. 65Đ108.

Omar, N.A.M., Mousa, A., El-Husseini, M.M. and ElBishry, M.H., 2005. Changes in lipid contents due to infection with Bacillus thuringiensis Kurstaki in larvae of the greater wax moth Galleria mellonella L., (Lepidoptera: Galleridae). Egypt. J. Biol. Pest Contr., 15: 41-44.

Otitoloju, A.A., 2001. Joint action toxicity of heavy metals and their bioaccumulation by benthic animals of the Lagos lagoon. $\mathrm{Ph}$. D. dissertation, University of Lagos. pp. 234.

Phillips, T.W. and Throne, J.E., 2010. Biorational approaches to managing stored-product insects. Annu. Rev. Ent., 55: 375D397. https://doi. org/10.1146/annurev.ento.54.110807.090451

Riaz, T., Shakoori, F.R. and Ali, S.S., 2014. Effect of temperature on the development, survival, fecundity and longevity of stored grain pest, Trogoderma granarium. Pakistan J. Zool., 46: 1485-1489.

Riaz, T., Shakoori, F.R. and Ali, S.S., 2018. Phosphineinduced alterations in microsomal enzymes of a stored grain pest Trogoderma granarium collected from godowns of Punjab, Pakistan. Pakistan J. Zool., 50: 291-297. https://doi.org/10.17582/ journal.pjz/2018.50.1.291.297

Riaz, T., Shakoori, F.R., Mansoor, H., Khan, S. and Saleem, M.A., 2019. Efficacy of mixture of pesticides on the mortality and energy reserves of a stored grain pest Trogoderma granarium Everts. Pakistan J. Zool., 51: 2297-2309. https:// doi.org/10.17582/journal.pjz/2019.51.6.2297.2309

Roe, J.H. and Dailey, R.E., 1966. Determination of glycogen with anthrone reagent. Anal. Biochem., 15: 245-250. https://doi.org/10.1016/00032697(66)90028-5

Rossi, E., Cosimi, S. and Loni, A., 2010. Insecticide resistance in Italian populations of Tribolium castaneum flour beetles. Bull. Insectol., 63: 251258.

Saleem, M.A. and Shakoori, A.R., 1990. The toxicity of eight insecticides to sixth instar larvae and adult beetles of Tribolium castaneum (Herbst.). Pakistan J. Zool., 22: 207-216.

Shah, M.A. and Khan, A.A., 2014. Use of diatomaceous earth for the management of stored-product pests. Int. J. Pest Manage., 60: 100-113. https://doi.org/1 0.1080/09670874.2014.918674

Shakoori, A.R., Agha, S., Malik, M.Z., Saleem, M.A. and Ali, S.S., 1994. Biochemical abnormalities produced by sublethal doses of a synthetic pyrethroid, Sumicidan Super, on the $6^{\text {th }}$ instar larvae of red flour beetle, Tribolium castaneum. Pakistan J. Ent., 9: 5-20.

Shakoori, A.R., Ismail, S., Zulfiqar, S. and Mujeeb, K.M., 2004. Effect of a-cypermethrin on esterases of sixth instar larvae and 10 days old adults of three different strains of Tribolium castaneum. Pakistan J. Zool., 36: 173-188.

Shakoori, F.R., Feroz, A., Gondal, A., Akram, S and Riaz, T., 2018. Impact of Lambda-Cyhalothrin on carbohydrate metabolizing enzymes and macromolecules of a stored grain pest, Trogoderma granarium.PakistanJ.Zool.,50: 1467-1474.https:// doi.org/10.17582/journal.pjz/2018.50.4.1467.1474

Shakoori, F.R., Feroze, A. and Riaz, T., 2016. Effect of sub-lethal doses of phosphine on macromolecular concentrations and metabolites of adult beetles of stored grain pest, Trogoderma granarium, previously exposed to phosphine. Pakistan J. Zool., 48: 583-588.

Shakoori, F.R., Riaz, T., Ramzan, U., Feroz, A. and Shakoori, A.R., 2018. Toxicological effect of esfenvalerate on carbohydrate metabolizing enzymes and macromolecules of a stored grain pest, Trogoderma granarium. Pakistan J. Zool., 50: 2185-2192. https://doi.org/10.17582/journal. pjz/2018.50.4.1467.1474

Shaurub, E.S.H. and El-Aziz, N.M.A., 2015. Biochemical effects of lambda-cyhalothrin and lufenuron on Culex pipiens L. (Diptera: Culicidae). 
Int. J. Mosq. Res., 2: 122-126.

Sherma, S.S., 1989. Review of literature of the losses caused by Callosobruchus species (Bruchidae: Coleoptera) during storage of pulses. Bull. Grain Technol., 22: 62-68.

Shoba, V., Elanchezhiyan, C., Hemalatha, S. and Selvisabanayakam, S., 2011. Sublethal effect of phytopesticide nimbecidine on biochemical changes in the adult male insect Sphaerodema rusticum (Heteroptera: Belostomatidae). Int. J. Res. Pharm., 2: 12-17.

Stathers, T., Denniff, M. and Golob, P., 2004. The efficacy and persistence of diatomaceous earths admixed with commodity against four tropical stored product beetle pests. J. Stored Prod. Res., 40: 113-123. https://doi.org/10.1016/S0022474X(02)00083-8

Steele, J.E. and Paul, T., 1985. Corpus cardiacum stimulated trehalose efflux from cockroach (Periplaneta americana) fat body: Control by calcium. Can. J. Zool., 63: 63-66. https://doi. org/10.1139/z85-012

Talukder, F.A. and Howse, P.E., 1993. Deterrent and insecticidal effects of extracts of pithraj, Aphanamixis polystachya (Meliaceae) against Tribolium castaneum, in storage. J. chem. Ecol., 19: https://doi.org/10.1007/BF00980683

Vassilakos, T.N., Athanassiou, C.G. and Thiropolous, N.G., 2015. Persistence and efficacy spinetoram against major stored grain beetles on wheat. Crop. Prot., 69: 44-51. https://doi.org/10.1016/j. cropro.2014.08.010

Vayias, B.J. and Vassiliki, K.S., 2009. Factors affecting the insecticidal efficacy of an enhanced diatomaceous earth formulation against three stored-product insect species. J. Stored Prod. Res., 45: 226-231. https://doi.org/10.1016/j. jspr.2009.03.002

Vayias, B.J., Athanassiou, C.G. and Buchelos, C.Th., 2009. Effectiveness of spinosad combined with diatomaceous earth against different European strains of Tribolium confusum du Val (Coleoptera:
Tenebrionidae): influence of commodity and temperature. J. Stored Prod. Res., 45: 165-176. https://doi.org/10.1016/j.jspr.2008.11.002

Wakil, W., Yasin, M., Qayyum, M.A., Ghazanfar, U., Al-Sadi, A.M., Bedford, G.O. and Kwon, Y.J., 2018. Resistance to commonly used insecticides and phosphine fumigant in red palm weevil, Rhynchophorus ferrugineus (Olivier) in Pakistan. PLoS One, 13: 1-11. https://doi.org/10.1371/ journal.pone. 0192628

Ware, G.W. and Whitacre, D.M., 2004. The pesticidebook. Meister Pro Information Resources, Willoughby, $\mathrm{OH}$.

White, N.D.G. and Lessch, J.G., 1995. Chemical control. In: Intregated pest management of insects in stored products. Marcel Dekker, Inc., New York, USA.

World Health Organisation (WHO), 2009. The WHO Recommended classification of pesticides by hazard guidelines to classification 2009. International Program on Chemical Safety (IPCS), Inter-Organisational Programme for the Sound Management of Chemicals (IOMC). www.who.int/ ipcs/publications/pesticideshazard/en/. Accessed 12 August 2016.

Yadav, J., Yadav, J.L., Saini, R.K. and Devi, M., 2018. Stored grain pests incidence in wheat with particular reference to khapra beetle, Trogoderma granarium Everts in Southern Haryana, India. Int. J. Curr. Microbiol. appl. Sci., 7: 2179-2186. https:// doi.org/10.20546/ijcmas.2018.703.257

Yazdani, E., Sendi, J.J., Aliakbar, A. and SenthilNathan, S., 2013. Effect of Lavandula angustifolia essential oil against lesser mulberry pyralid Glyphodes pyloalis Walker (Lep: Pyralidae) and identification of its major derivatives. Pestic. Biochem. Physiol., 107: 250-257. https://doi. org/10.1016/j.pestbp.2013.08.002

Zollner, N. and Kirsch, K., 1962. Microdetermination of lipids by the sulfo-phosphovanillin reaction. $Z$. Gecexp. Med., 135: 545-561. 